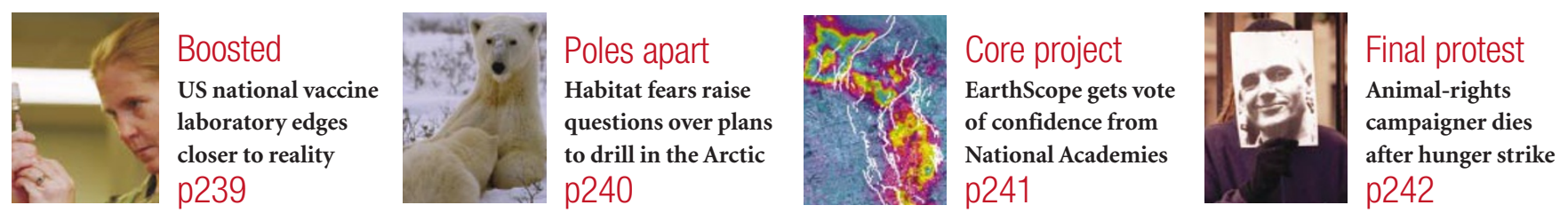

\title{
Biologists urged to address risk of data aiding bioweapon design
}

\section{Peter Aldhous, London}

Biologists must begin a process of selfregulation for projects that have potential applications in developing bioweapons or risk the imposition of restrictive controls from outside. That is the sobering message being delivered by a senior scientific adviser to the US defence department.

George Poste, who chairs a Department of Defense task force on bioterrorism and sits on its advisory Defense Science Board, told a pharmaceuticals-industry conference in London on 6 November that biology must "lose its innocence". He criticized biologists for what he regards as their naivety in failing to consider malign applications of data generated in legitimate projects, and urged them to start considering how access to such data could best be regulated.

"What I think is untenable is the status quo - just allowing highly sensitive information to enter the public domain," says Poste, a former head of research at the drugs company

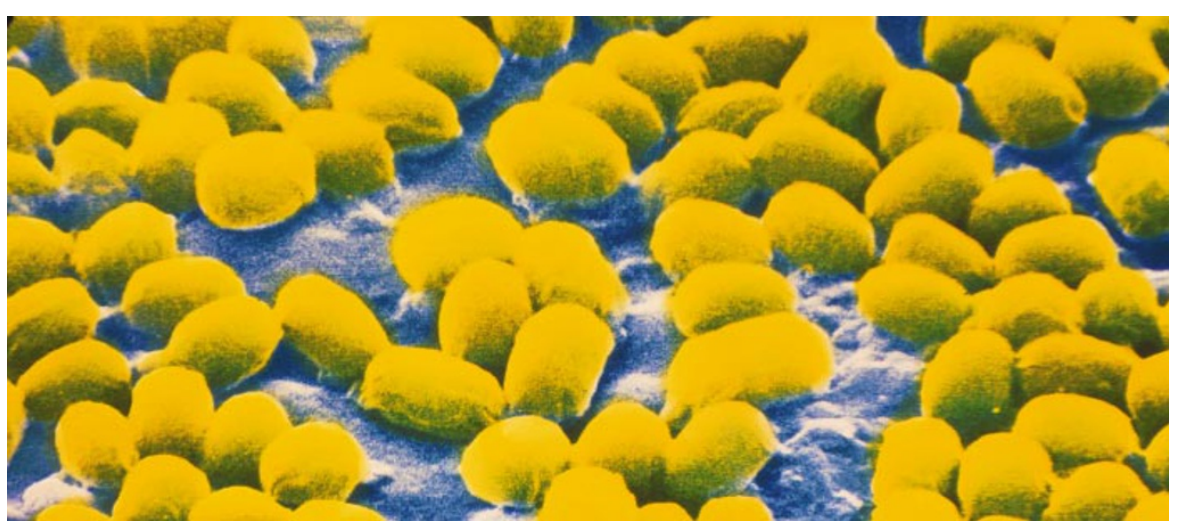

Fear factor: restrictions could extend beyond work on bioweapons agents such as these anthrax spores.

SmithKline Beecham. "Equally dangerous would be a draconian legislative response."

With the United States reeling in the face of anthrax attacks against media outlets and politicians, Poste fears that unduly restrictive legislation could be hurried through. $\mathrm{He}$ points to a bill that is now before Congress that

\section{CERN opens finances up for review}

\section{David Adam, London}

CERN, the European Laboratory for Particle Physics near Geneva, is seeking help from outside experts as it struggles to find a way through the funding crisis triggered by cost overruns on its Large Hadron Collider (LHC) project.

At a meeting of the laboratory's finance committee on 6 November, CERN managers said they would appoint an external review board to assess future financing needs through to 2012 for both the LHC and the lab as a whole. The board will be set up later this month and should produce a preliminary report by the end of this year, with a final one to follow in June 2002.

The laboratory's effort to build the LHC, the world's most powerful proton accelerator, has gone over budget by several hundred million dollars (see Nature 413, 441; 2001).

In a statement posted on its website on 16 October, CERN's director-general,
Luciano Maiani, hinted strongly that the LHC could not be completed without more money from the member states. "CERN's capacity to absorb these extra costs has been severely limited," he wrote. "Support from the governments and funding agencies is now essential to reach a solution."

But at the finance meeting, several delegates insisted that there would be no extra contributions from them to bail out the project.

Neil Calder, a spokesman for CERN, says that Maiani's call for support was not necessarily a request for more money. He claims that, if required, CERN could build the LHC without extra contributions but "that would not be the optimum solution".

Meanwhile, CERN has appointed four internal 'task forces' to find savings from its research programmes, its staffing, its industrial links and its organizational structure. would impose sweeping restrictions on nonUS citizens handling potential bioweapons agents, which has already caused alarm among biologists (see Nature 414,3-4; 2001).

In an interview with Nature, Poste expanded upon his concerns. He is particularly worried about projects in which viruses are engineered to evade or manipulate the immune system. For instance, earlier this year Australian researchers revealed that they had inadvertently created a supervirulent strain of mousepox in a project aimed at creating a contraceptive vaccine (see Nature 411, 232-235; 2001). And gene therapists, grappling with the problems caused by immune reactions to the viral vectors they use to introduce therapeutic genes, are now designing 'stealth' vectors that would escape the attention of the immune system.

Such technologies could be applied to viral bioweapons with devastating effects, argues Poste. Yet he has been disappointed by the reactions of some researchers working on such projects when this possibility is raised: "They look at you first of all with a blank stare, followed by arrogant denial," he says.

Poste believes that a larger number of projects addressing the issue of biodefence may in future have to be classified. More generally, he suggests that researchers submitting grant proposals to bodies such as the National Institutes of Health (NIH) might have to declare whether they have considered potential malign applications. For projects deemed to be particularly risky, manuscripts 


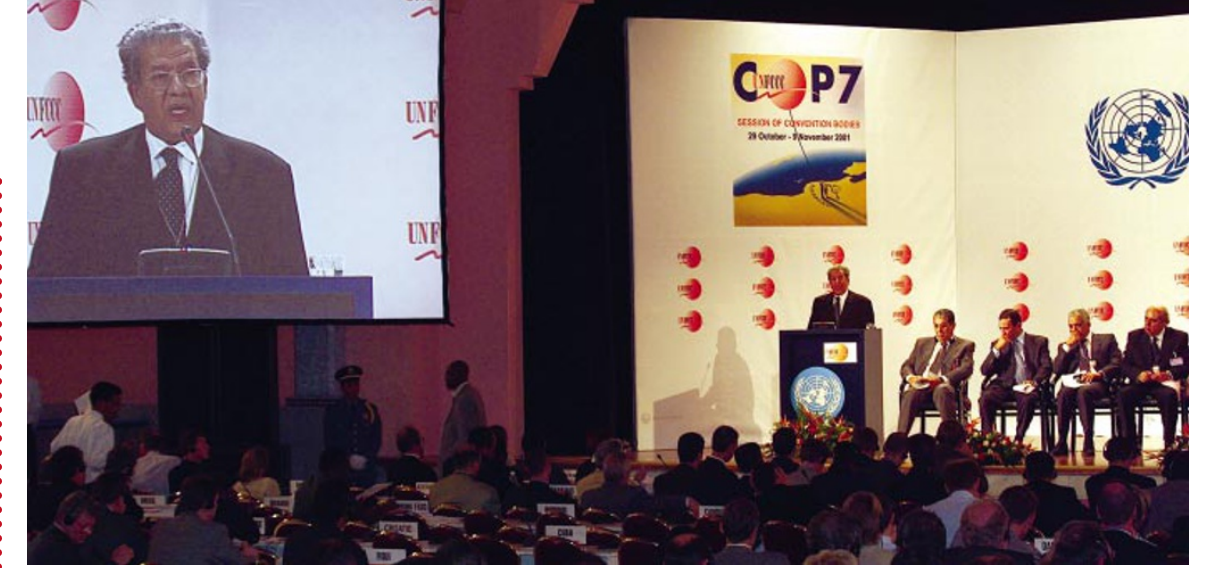
appropriate framework for self-regulation. "These are not formal proposals," he says.

Poste's suggestions are highly controversial, given that the freedom to publish and to share data is central to the culture of mod-

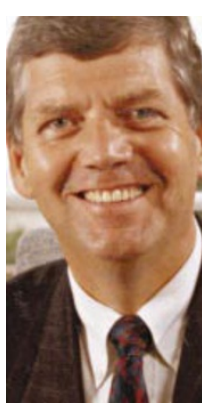

George Poste: wants to restrict access to data. ern bioscience. "We consider openness in publication as sacrosanct in our work," says Tony Fauci, director of the National Institute of Allergy and Infectious Diseases in Bethesda, Maryland. "I think that's something that we are going to have to be very careful about treading on."

Fauci is similarly sceptical about proposals to restrict access to genome-sequence databases. "I'm not sure how much safer the public would be" as a result of such controls, he says.

Gene therapists, who are already subject to stringent controls, view any suggestion of additional regulation with horror. "I spend $90 \%$ of my time dealing with regulatory authorities," says Malcolm Brenner of Baylor College of Medicine in Houston, Texas, president of the American Society of Gene Therapy. "Any further regulation will be the kiss of death."

Mark Wheelis, a microbiologist at the University of California, Davis, and a member of the Federation of American Scientists' working group on bioweapons, is alarmed by Poste's suggestion of classifying a greater proportion of work on defence against bioweapons. He argues that this could allow states to hide offensive bioweapons programmes under the guise of classified biodefence projects - or at least to create suspicions that they are doing so.

On the basis of his conversations with members of Congress, Fauci says he is confident that legislators will not impose draconian restrictions. But both he and Wheelis agree that biologists must become more aware of potential destructive applications of their work. They urge scientific societies to take a lead in promoting debate.

Fauci says the NIH could play a part by hosting discussion meetings, and believes that heightened awareness could lead to biologists deciding not to go ahead with certain projects.

a

Optimistic: delegates at the Marrakech meeting believe the Kyoto Protocol could soon come into force. Accord in Morocco breathes
fresh life into Kyoto Protocol

\section{Quirin Schiermeier}

The Kyoto Protocol on climate change now has an official rulebook, agreed by delegates from more than 160 countries in Marrakech, Morocco.

The agreement, reached at a meeting that began on 29 October, was thrashed out in the early hours of 10 November, after a final 18-hour negotiating session. It has triggered optimism that the treaty will come into force before the World Summit on Sustainable Development, to be held next September in Johannesburg, South Africa.

Contentious questions in Marrakech included the eligibility of industrialized countries to buy and sell rights to emit greenhouse gases, methodologies for reporting and monitoring emissions and emissionreduction activities, and penalties for countries failing to achieve their emission targets.

To come into force, the Kyoto Protocol must be ratified by a minimum of 55 countries that together accounted for at least 55\% of global carbon-dioxide emissions in 1990. The United States, the world's largest emitter, still says that it will not ratify the protocol.

This means that the European Union (EU) and the 'Umbrella Group' of industrialized countries - including Japan, Canada, Australia and Russia - are needed to reach the $55 \%$ emissions target. Although the EU is enthusiastic, members of the Umbrella Group have, until now, been reluctant.

To make ratification palatable to Russia, delegates agreed that credits for its natural carbon 'sinks', mainly forests, could be almost doubled to 33 million tonnes of carbon per year. Russia hopes to profit from unused rights to emit greenhouse gases, and now says it will ratify the protocol.

Japan also won concessions that will make market-based mechanisms, such as emissions trading, fully available to all industrialized countries, regardless of whether or not they meet their targets and report their emissions adequately.

But a decision on the legal status of penalties for countries that fail to meet their targets was deferred to the first meeting of parties after the treaty has come into force.

\section{Blow to German stem-cell prospects}

\section{Alison Abbott, Munich}

A cross-party parliamentary commission on bioethics has cast a majority vote against research involving any human embryonic stem (ES) cells in Germany.

The 12 November vote, which came out 17 to 7 , will be taken into consideration next January, when the German parliament debates whether to close a legal loophole allowing human ES cells to be imported. In Germany, isolating the cells from human embryos is forbidden.

The situation puts more pressure on the DFG, Germany's main research granting agency, which has twice delayed a decision to release money for a research project on imported human ES cells. The agency approved the project in principle in May (see Nature 411, 875; 2001).

The DFG had hoped that the parliament would have debated the issue before the agency's main committee meeting on 7 December, at which the project was scheduled to be discussed. But events in the United States and Afghanistan have forced ES cells down the political agenda.

Scientists are disappointed by the commission's vote. But they anticipate that the National Ethics Council, which was created by Chancellor Gerhard Schröder earlier this year, will be more favourably disposed towards regulated imports of human ES cells. The National Ethics Council will report next week. 